\title{
ANALISIS TREN SEMASA DEMOGRAFI PERSONEL PENYENGGARAAN BANGUNAN WARISAN DI MALAYSIA
}

\author{
M.A.A. Rahman'1, Z.A. Akasah ${ }^{2}$, S.N.F. Zuraidi ${ }^{3}$ \\ 1Jabatan Kejuruteraan Pembinaan dan Senibina, ${ }^{2 \& 3}$ Jabatan Teknologi Kejuruteraan Awam. Fakulti \\ Kejuruteraan Awam dan Alam Sekitar, Universiti Tun Hussein Onn Malaysia \\ ashrafr@uthm.edu.my, zaina159@uthm.edu.my,
}

\begin{abstract}
Abstrak
Personel penyenggaraan merupakan antara keperluan sumber terpenting bagi sesebuah organisasi penyenggaraan. Tanpa personel penyenggaraan adalah mustahil kerja-kerja penyenggaraan sesebuah bangunan itu dapat dilaksanakan. Walaubagaimanapun, tinjauan literatur mendapati bahawa kebanyakkan personel penyenggaraan hari ini terdiri daripada kalangan yang tidak terlatih serta tidak berkelayakan. Jesteru itu, kajian ini dilakukan bagi mendapatkan tren semasa demografi personel penyenggaraan dalam praktis pengurusan penyenggaraan bangunan warisan di Malaysia. Instrumen kajian berupa set soalselidik dan diedarkan kepada setiap personel penyenggaraan yang terlibat dari beberapa buah bangunan warisan terpilih. Hasil kajian mendapati kurang satu pertiga daripada bilangan personel yang terlibat mempunyai kelayakan untuk menjalankan kerja-kerja penyelenggaraan di bangunan warisan. Ini membuktikan bahawa praktis penyelenggaraan hari ini tidak dilakukan oleh personel yang benar-benar berkelayakan. Kajian ini diharap dapat memberi gambaran semasa berkenaan dengan praktis penyenggaraan bangunan warisan dan seterusnya membuka ruang untuk penambahbaikan di masa hadapan.
\end{abstract}

Kata kunci: bangunan warisan, penyenggaraan, personel, tren demografi

\begin{abstract}
Maintenance personnel are among the most important source for maintenance organizations. Without them, it is imposible for maintenance works to be done in a building. However, the literature review found that most of today's personnel of those who are not well trained and qualified. Therefore, these study is done to obtain demographic trends amongs the maintenance personnel of a heritage buildings in Malaysia. Set of research questionnaires which consist of demographic backgrounds are distributed to the personnel involved in the maintenance work of selected heritage buildings. The emperical study then is conducted in order to obtain personnels thought of the main problem in maintaining heritage buildings and how to overcome the arising problems. At the end of the discussion, a conclusion is formed as a response to the findings. It is hopefully that this reseach will lead for further improvement in maintaining and managing the heritage building more effectively.
\end{abstract}

Keywords: demographic trends, heritage buildings, maintenance, personnel 


\section{Pengenalan}

Sebagai sebuah bangunan yang telah dikategorikan sebagai aset warisan, keperluan penyenggaraan terhadapnya tidak boleh diabaikan (ICOMOS, 1999; ICOMOS, 1964). Ini kerana bangunan yang sudah dipulihara ini perlu kepada perlindungan dan pengawalan terhadap kondisi dan juga fungsi bagi meneruskan kelangsungan hayat bangunan ini untuk masa yang akan datang (Ahmad A.G., 2006; Maintain Our Heritage, 2004). Tanpa penyenggaraan, adalah mustahil bagi bangunan yang sudah berusia ini untuk terus kekal pugar dan bertahan dengan prestasi yang cekap dan selamat (Mohammad Ashraf et. al., 2012; Hakim dan Min, 1991).

Walaupun bangunan warisan secara amnya telah menjalani proses pemuliharaan sebelum pewartaannya, namun itu tidak bermakna bahawa bangunan tersebut akan bebas dari sebarang masalah bangunan kelak. Ahmad Ramly (2002) menyatakan bahawa masalah bangunan hari ini adalah berbeza dengan keperluan dan pemeliharaannya dari masa-masa lalu dan akan berbeza juga untuk masa-masa akan datang. Penyataan tersebut secara ringkasnya menyimpulkan bahawa prestasi sesebuah bangunan itu amat berhubungkait dengan penyenggaraan(Akasah et.al., 2011). Dalam erti kata yang mudah, bangunan yang tidak diurus senggara secara baik pada hari ini akan memberi masalah yang lebih besar di masa yang akan datang (Akasah dan Alias, 2009).

Sebagai memenuhi keperluan perundangan Akta Warisan Kebangsaan 2005 (Akta 645) (Jabatan Warisan Negara (2005), urusan penyenggaraan bagi bangunan yang telah diwartakan perlulah diuruskan secara profesional berdasarkan prinsip dan prosedur penyenggaraan yang betul. Ahmad A.G. (2006) menegaskan bahawa pengurusan yang profesional bukan sahaja perlu sewaktu kerja pemuliharaan bangunan tetapi juga penting di peringkat pasca pemuliharaan. Ini bagi memastikan bahawa kesilapan atau kecuaian yang mungkin memberi mudarat kepada fabrik, kandungan serta perletakan sesebuah bangunan warisan itu dapat dielakkan. Oleh itu, menurut Kayan dan Zuraini (2003), adalah menjadi suatu yang penting bagi pihak pengurusan memastikan personel yang menjalankan kerja-kerja penyenggaraan ke atas bangunan adalah benar-benar layak, mahir dan dan berpengalaman untuk menjalankan kerja-kerja berkaitan pengekalan bangunan.

Namun, senario hari ini memperlihatkan profesyen penyenggaraan tidak lagi diminati dan kurang diberi perhatian yang sewajarnya (Mohammad Ashraf et. al., 2010; Wood, 1999). Ini kerana tanggapan sesetengan pihak yang melebelkan profesyen ini sebagai kerjaya berstatus rendah dan kurang popular (Seeley, 1976) serta sering berurusan dengan perkara-perkara yang kotor dan menjijikkan (Jones dan Collis, 1996). Oleh itu tidak hairanlah sekiranya kerjaya ini lebih didominasi oleh golongan yang tidak berkelayakan sebagai personel penyenggaraan (Adi Irfan, 2009). Situasi ini telah menjadi satu kesempatan yang baik dikalangan para pengusaha organisasi penyenggaraan di mana penjimatan kos buruh dapat diminimakan. Ini kerana upah yang dibayar oleh pihak organisasi adalah berdasarkan kepada kelayakan personel yang digajikan (Kementerian Sumber Manusia, 2011). Sekiranya personel tersebut tidak mempunyai kelayakan, sama ada dari segi akademik, kemahiran atau pengalaman maka bayaran yang diterimanya adalah jauh lebih rendah berbanding personel yang mempunyai kelayakan. Walaupun kelemahan ini memberi satu 
kelebihan kepada organisasi penyenggaraan namun impak dari kelemahan ini mempengaruhi mutu kerja penyenggaraan ke atas sesebuah bangunan (Akasah dan Alias, 2009).

Bagi menghurai lebih terperinci mengenai situasi semasa ini, kertas ini membincangkan mengenai tren demografi personel penyenggaraan yang terlibat dalam mengurus senggara bangunan warisan di Malaysia. Sebagai permulaan, sebanyak tiga kompenen utama demografi personel telah dikaji iaitu demografi berkaitan gender, akademik dan pengalaman kerja. Kajian emperikal seterusnya adalah mengkaji permasalahan utama personel dan strategi penambahbaikan kualiti personel dalam membantu mempertingkatkan mutu kerja penyenggaraan di masa hadapan.

\section{Metadologi dan Pengumpulan Data}

Responden kajian terdiri daripada personel penyenggaraan yang terlibat secara langsung dalam mengurus senggara bangunan warisan. Jumlah keseluruhan responden yang terlibat adalah seramai 88 orang. Setiap responden dibekalkan dengan set soal selidik yang mengandungi 2 bahagian utama. Bahagian pertama soal selidik adalah berkaitan dengan demografi personel yang terdiri daripada 3 soalan aneka pilihan dan responden diminta untuk memberikan jawapan berdasarkan pilihan jawapan yang disediakan. Sementara itu, bahagian dua soal selidik adalah berkaitan dengan permasalahan utama dan cadangan pemerkasaan personel. Responden diminta untuk menyenaraikan pilihan jawapan mengikut skala 1 sehingga skala 5 berdasarkan skala likert. Skala "1" bermaksud tidak mempengaruhi manakala skala " 5 " bermaksud sangat mempengaruhi. Data kemudian dianalisis menggunakan rumus indeks kepentingan seperti di bawah:

$$
\begin{aligned}
& \left(\sum_{i=1}^{5} w_{i} \times f x_{i}\right) \times 100 / 5 n \\
& \text { di mana, } \\
& w i=\text { skala respon; } i=1,2,3,4 \text { atau } 5 \\
& f x i=\text { frekuensi respon; } i=1,2,3,4 \text { atau } 5 \\
& n \quad=\text { bilangan responden }
\end{aligned}
$$

\section{Pemilihan Bangunan}

Pemilihan bangunan adalah berdasarkan kepada 3 kriteria utama yang telah ditetapkan iaitu bangunan yang melebihi 100 tahun, telah siap dipulihara dan diwartakan sebagai bangunan warisan dan urusan penyenggaraan dilakukan oleh organisasi penyenggaraan. Sebanyak 4 buah bangunan telah dipilih dari 2 buah bandar di Malaysia iaitu Pulau Pinang dan Melaka. Pemilihan ini dibuat memandangkan kedua-dua buah bandar ini terletak dalam kawasan Tapak Warisan Dunia UNESCO. Perincian bangunan adalah seperti yang dipersembahkan dalam Jadual 1 di bawah: 
Jadual 1: Perincian Bangunan Warisan

\begin{tabular}{|c|c|c|c|c|c|}
\hline \multirow{2}{*}{ Bangunan } & \multirow{2}{*}{ Lokasi } & \multirow{2}{*}{ Tahun dibina } & \multicolumn{2}{|c|}{ Bilangan Personel } & \multirow{2}{*}{ Jumlah } \\
\cline { 4 - 5 } & & & Teknikal & Pentadbiran & \\
\hline Bangunan 1 & Pulau Pinang & 1883 & 9 & 12 & 21 \\
\hline Bangunan 2 & Pulau Pinang & 1898 & 15 & 9 & 24 \\
\hline Bangunan 3 & Melaka & 1886 & 11 & 12 & 23 \\
\hline Bangunan 4 & Melaka & 1888 & 14 & 6 & 20 \\
\hline \multicolumn{3}{|c|}{ Jumlah } & $\mathbf{4 9}$ & $\mathbf{3 9}$ & $\mathbf{8 8}$ \\
\hline
\end{tabular}

\section{Analisis dan Perbincangan}

\subsection{Analisis dapatan}

Dapatan yang diperolehi hasil daripada maklumbalas responden di analisis dan dipersembahkan dalam bentuk data grafik (Rajah 1 - 3) dan jadual (Jadual 1 dan 2). Data kemudiannya dibincangkan mengikut perincian yang berikut:

\subsubsection{Demografi gender}

Daripada keseluruhan 88 orang personel penyenggaraan yang dipilih, didapati bahawa profesyen penyenggaraan ini lebih didominasi oleh golongan lelaki. Berdasarkan Rajah 1, hanya terdapat 19 personel wanita sahaja yang melibatkan diri di dalam profesyen ini dan keterlibatan wanita ini lebih kepada menguruskan hal-hal berkaitan pentadbiran dan pengkeranian. Hanya sebilangan kecil sahaja wanita yang terlibat dalam kerja teknikal seperti pembersihan dan pencucian manakala sebahagian besar yang lain adalah lelaki.

\subsubsection{Demografi akademik}

Latar belakang akademik mempunyai perhubungan langsung dengan tahap pendidikan yang diterima oleh seseorang personel. Berdasarkan Rajah 2, didapati bahawa kurang 20 orang personel yang mendapat pendidikan tinggi diperingkat diploma dan ijazah. Kebanyakkan personel diperingkat ini adalah wanita dan memegang jawatan diperingkat pentadbiran. Sementara itu, personel yang menerima pendidikan di peringkat sijil kemahiran adalah sebanyak 35\% dan hampir kesemua personel ini mendominasi bidang teknikal. Sebahagian besar personel yang lain adalah mereka yang mendapat pendidikan formal di peringkat sekolah dan tidak mempunyai pendidikan asas dalam bidang teknikal dan berkemahiran.

\subsubsection{Demografi pengalaman}

Daripada survei yang dilakukan, hampir $50 \%$ personel penyenggaraan mempunyai pengalaman kurang daripada 2 tahun. Hanya 8 orang sahaja yang mempunyai pengalaman kerja melebihi 6 tahun dan kesemua mereka bekerja diperingkat pentadbiran. Manakala baki 38 orang mempunyai pengalaman antara 2 hingga 6 tahun. Pecahan demografi pengalaman kerja ditunjukkan dalam Rajah 3. 
Rajah 1: Pecahan Personel mengikut demografi gender

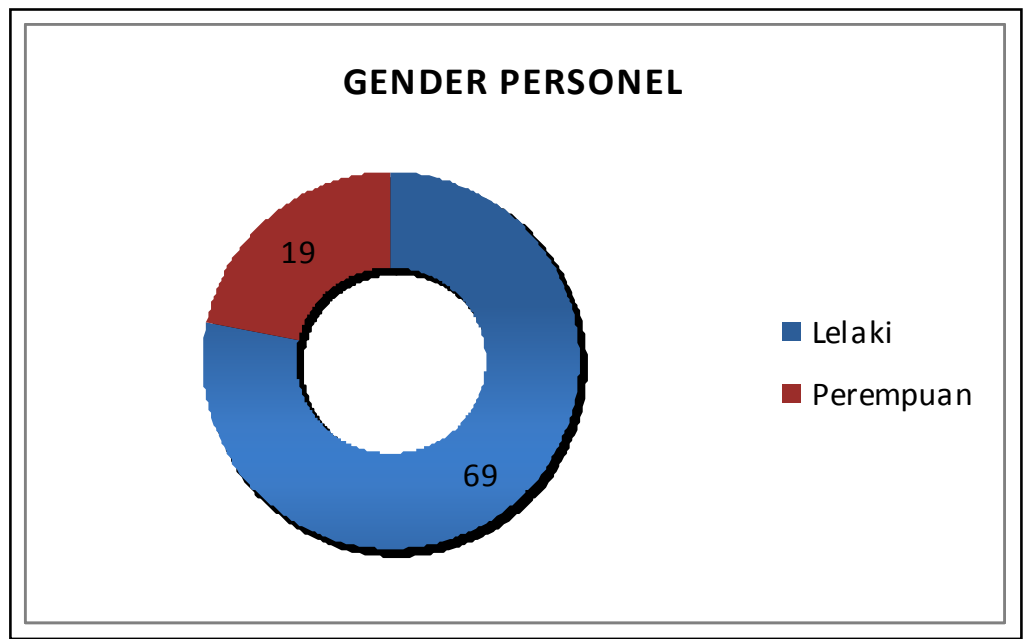

Rajah 2: Pecahan Personel mengikut demografi akademik

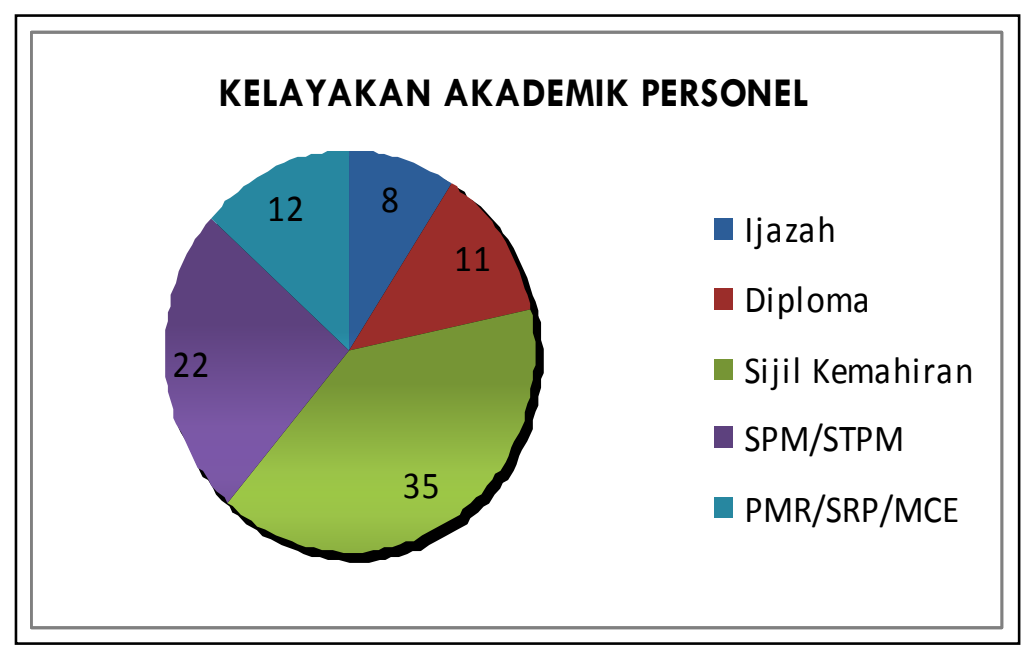

Rajah 3: Pecahan Personel mengikut demografi pengalaman

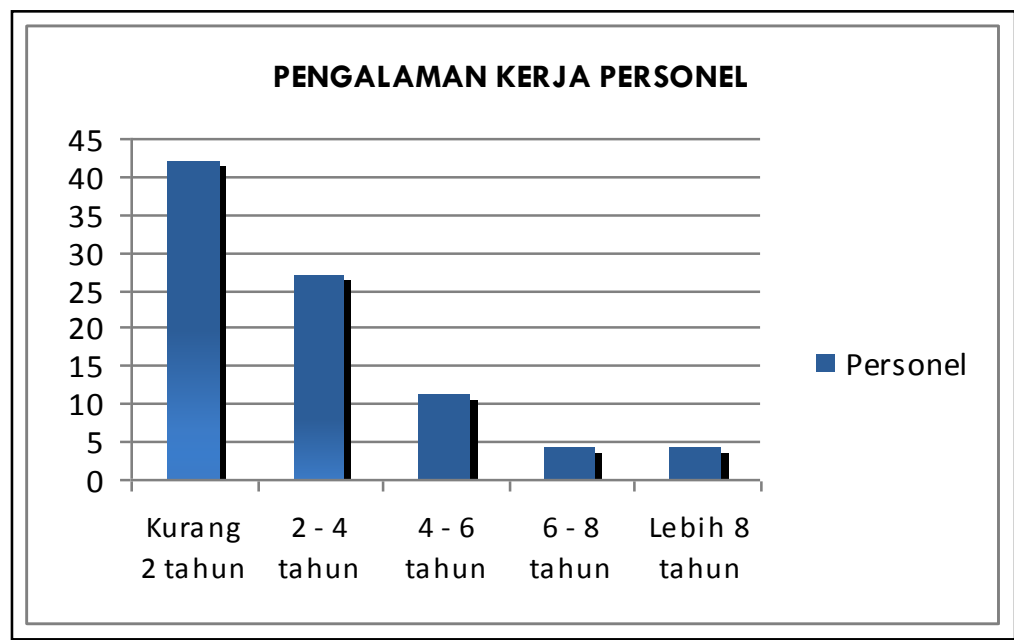




\subsection{Perbincangan}

Daripada kajian yang dilakukan, didapati bahawa profesyen penyenggaraan lebih disominasi oleh golongan lelaki berbanding wanita berikutan persekitaran kerja yang menuntut aktiviti fizikal dan lasak. Namun begitu, penyertaan golongan wanita dilihat amat ketara dalam urusan pentadbiran dan pengkeranian.

Dari aspek pendidikan pula, didapati bahawa praktis semasa penyenggaraan tidak menjadi pilihan dari kalangan tenaga kerja yang berpendidikan tinggi. Walaupun terdapat sebahagian daripada personel penyenggaraan tersebut mempunyai kelayakan diploma dan ijazah, namun hanya sedikit sahaja yang bergraduasi dalam bidang berkaitan penyenggaraan. Manakala sebahagian personel-personel yang lain datang dari disiplin yang berbeza seperti dari bidang perakaunan dan perdagangan. Keadaan ini menyukarkan aktiviti kerja penyenggaraan kerana personel-personel ini tidak mempunyai pendedahan akademik berkaitan penyenggaraan. Bilangan personel yang dikategorikan sebagai berkemahiran juga adalah tidak ramai. Kekurangan personel yang berpendidikan tinggi dan berkemahiran secara langsung memberi kesan terhadap pengurusan kerja dan situasi ini turut mempengaruhi perlaksanaan kerja. Ini kerana kerja-kerja penyenggaraan bangunan warisan memerlukan kefahaman yang tinggi sama ada dari aspek penyenggaraan mahupun dari aspek bangunan warisan. Kegagalan memahami kedua-dua aspek tersebut berkemungkinan besar akan mendorong kepada praktis yang bersalahan serta mendedahkan bangunan tersebut kepada permasalahan yang lebih besar kelak.

Sementara itu, tidak ramai personel yang didapati mempunyai pengalaman kerja melebihi 2 tahun. Ini menunjukkan bahawa perlaksaan kerja-kerja penyenggaraan dipengaruhi oleh golongan yang kurang berpengalaman. Merujuk kepada analisis yang diperolehi, kurang daripada 10 orang personel yang mempunyai pengalaman lebih 6 tahun dan didapati juga bahawa kesemua personel tersebut merupakan tonggak utama dalam organisasi terbabit.

\subsection{Kajian emperikal}

\subsubsection{Permasalahan utama personel}

Merujuk kepada Jadual 2, permasalahan utama yang dihadapi oleh personel penyenggaraan dengan indeks mempengaruhi sebanyak $81.14 \%$ adalah kekurangan bahan rujukan serta garispanduan yang dapat membantu mereka dalam perlaksanaan kerja-kerja penyenggaraan. Dalam masa yang sama juga, personel penyenggaraan tidak mendapat latihan serta tunjuk ajar yang komprehensif. Permasalahan ini secara langsung memberi impak kepada hasil kerja yang dilakukan kerana kebanyakkan personel tidak mendapat pendidikan khusus serta kurang berpengalaman dalam bidang penyenggaraan bangunan warisan. Selain itu, masalah kekurangan personel juga mempunyai indeks mempengaruhi tertinggi iaitu sebanyak $80.91 \%$. Akibat daripada kekurangan personel, terdapat sebahagian personel yang terpaksa memikul beban kerja yang lebih dari sepatutnya dan secara tidak langsung menjadikan penggunaan tenaga kerja yang tidak efektif. Seterusnya, bayaran serta gaji yang diterima oleh personel penyenggaraan turut menjadi masalah dengan indeks mempengaruhi sebanyak $80.68 \%$. Rata-rata personel tidak bersetuju dengan gaji 
yang diterima namun secara justifikasi kos upah personel adalah bersandarkan kepada kelayakan personel itu sendiri. Bagi mendapatkan bayaran yang tinggi maka para personel perlu mempersiapkan diri mereka dengan kelayakan yang diperlukan. Manakala dua lagi permasalahan tidak dilihat sebagai permasalahan yang sangat mempengaruhi personel iaitu arahan kerja yang tidak jelas dan personel tidak ditempatkan mengikut pengkhususan kerja yang bersesuaian memandangkan indeks mempengaruhi masing-masing adalah $57.73 \%$ dan $57.27 \%$.

\section{Jadual 2: Indeks Permasalahan Utama Personel}

\begin{tabular}{|c|l|c|}
\hline Bil. & Permasalahan Utama Personel & Indeks Mempengaruhi (\%) \\
\hline $\mathbf{1}$ & Kurang rujukan/garispanduan/latihan & 81.14 \\
\hline $\mathbf{2}$ & Kekurangan personel penyenggaraan & 80.91 \\
\hline $\mathbf{3}$ & Bayaran/gaji yang tidak berpatutan & 80.68 \\
\hline $\mathbf{4}$ & Arahan kerja tidakjelas & 57.73 \\
\hline $\mathbf{5}$ & Pengkhususan kerja tidak bersesuaian & 57.27 \\
\hline
\end{tabular}

\subsubsection{Cadangan pemerkasaan personel}

Berdasarkan Jadual 3 di bawah, penstrukturan semula bayaran atau gaji yang diterima menjadi cadangan yang mempunyai indeks mempengaruhi paling tinggi iaitu sebanyak 95.23\%. Namun begitu, ganjaran dalam bentuk kewangan ini sangat dipengaruhi oleh kos sara hidup dan lokasi kerja. Sebagai contoh, personel yang bekerja di Kuala Lumpur mempunyai kos sara hidup yang lebih tinggi berbanding personel yang bekerja di Melaka. Sementara itu, kursus dan latihan serta pembelajaran di tempat kerja menjadi cadangan kedua tertinggi dengan indeks mempengaruhi sebanyak 86.82\%. Melalui kaedah ini, personel dapat mempertingkatkan penguasaan mereka dalam bidang penyenggaraan. Secara tidak langsung, bayaran dan gaji personel dapat diberikan pertimbangan oleh pihak pengurusan memandangkan personel telah didedahkan dengan pengetahuan dan kemahiran. Seterusnya, manual penyenggaraan turut menjadi agenda kepada pemerkasaan personel. Dengan adanya manual penyenggaraan, personel mempunyai bahan untuk dijadikan sumber rujukan dan panduan ke arah perlaksanaan kerja yang betul. Walaubagaimanapun, penilaian kerja tahunan serta pengambilan personel berkelayakan tidak menjadi pilihan cadangan yang utama memandangkan kedua-dua cadangan tersebut mempunyai nilai indeks kurang daripada 50\%. Melalui dapatan ini, sememangnya pengambilan personel berkelayakan tidak mempengaruhi cadangan pemerkasaan personel. Ini menyebabkan wujudnya pelbagai masalah perlaksanaan penyenggaraan bangunan warisan apabila personel berkelayakan kurang atau tidak terlibat dengan operasi penyenggaraan.

Jadual 3: Indeks Cadangan Pemerkasaan Personel

\begin{tabular}{|c|l|c|}
\hline Bil. & \multicolumn{1}{|c|}{ Cadangan Pemerkasaaan } & Indeks Mempengaruhi (\%) \\
\hline $\mathbf{1}$ & Penstrukturan semula bayaran/gaji & 95.23 \\
\hline $\mathbf{2}$ & Kursus dan latihan di tempat kerja & 86.82 \\
\hline $\mathbf{3}$ & Manual penyenggaraan & 74.09 \\
\hline $\mathbf{4}$ & Penilaian kerja tahunan/prestasi & 48.41 \\
\hline $\mathbf{5}$ & Pengambilan personel berkelayakan & 43.86 \\
\hline
\end{tabular}




\section{Kesimpulan}

Kesimpulan daripada perbincangan ini secara keseluruhan membuktikan bahawa tren semasa demografi personel penyenggaraan bangunan warisan adalah lebih dikuasai oleh golongan yang tidak mempunyai kelayakan akademik yang bersesuaian serta kurang berpengalaman. Walaupun terdapat penglibatan dari golongan berpendidikan dan berpengalaman namun bilangannya agak kecil. Kebanyakkan personel yang berkelayakan ini lebih memfokuskan kepada urusan pentadbiran dan tidak terlibat secara langsung dalam perlaksanaan kerja penyenggaraan. Tren semasa ini secara tidak langsung mempengaruhi mutu kerja penyenggaraan dan seterusnya memberi impak terhadap usaha pemuliharaan yang telah dijalankan. Dalam masa yang sama, isu kekurangan bahan rujukan yang dapat membantu mempertingkatkan kefahaman di kalangan personel juga menjadi permasalahan utama kepada personel. Personel juga turut perlu memikul beban kerja yang lebih bagi menampung kekurangan pekerja. Situasi ini menjadikan penggunaan tenaga kerja yang tidak efektif dan secara tidak langsung menambahkan lagi kesukaran dalam usaha untuk menambahbaik kualiti personel. Sebagai langkah untuk masa hadapan, pembangunan personel menjadi agenda dalam memperkasakan personel melalui kaedah pembelajaran di tempat kerja serta memberikan kursus dan latihan kepada personel penyenggaraan. Di samping itu, manual kerja berkaitan penyenggaraan bangunan warisan juga dapat membantu personel untuk mempertingkatkan kefahaman dalam usrusan penyenggaraan. Secara tidak langsung, kredibiliti para personel akan lebih meningkat dan urusan penggajian personel dapat dipertimbangkan. Oleh yang demikian, adalah menjadi satu kepentingan dalam merubah tren semasa hari ini ke tahap yang lebih baik untuk hasil yang lebih efisien di masa hadapan.

\section{Rujukan}

Akasah, Z. A, Abdul, R. M. A and Zuraidi, S. N. F. (2011). Maintenance Management Success Factors for Heritage Building: A Framework. Structural Studies, Repairs and Maintenance of Heritage Architecture XII. WIT Transaction on The Built Environment, Vol. 118 @ 2011. ISBN: 978-1-84564-526-7; ISSN: 1743-3509 (0n-line)

Akasah, Z. A. and Alias, M. (2009). Application of The Generic Process Modelling in The Preservation of Heritage School Building. Structural Studies, Repairs and Maintenance of Heritage Architecture XI. WIT Transaction on The Built Environment, Vol. 109 @ 2009; ISSN: 1743-3509 (0n-line), doi: 10.2495/STR090291.

Adi Irfan C.A. et. al., (2009), Penyenggaraan Bangunan Resort Senibina Melayu di Malaysia, The Malaysian Surveyor, Vol.44, No.1, 2009

Ahmad A.G. (2006), Rangka kerja pemuliharaan bangunan warisan di Malaysia, Bengkel Konservasi Monumen dan Tapak Tanah Bersejarah, Melaka.

Ahmad Ramly (2002), Pengurusan Penyenggaraan Bangunan, Pustaka Ilmi, Malaysia.

International Council on Monuments and Sites (1964), The Venice Charter, International Council on Monuments and Sites, Paris. 
International Council on Monuments and Sites (1999), The Burra Charter, International Council on Monuments and Sites, Paris.

Hakim dan Min (1991), Teknologi Penyenggaraan Bangunan, Kuala Lumpur

Jabatan Warisan Negara (2005), Akta Warisan Kebangsaan 2005 (Akta 645), Kementerian Kebudayaan, Kesenian dan Warisan, Kuala Lumpur, International Law Book Services

Jones K. dan Collis S. (1996), Computerized Maintenence Management Systems (CMMS), Journal of Property Management, Vol. 14, No 4, 1996

Kementerian Sumber Manusia (2011), Labour and Human Resources Statistic 2010, Diperolehi pada Mac, 20, 2011, daripada laman web www.mohr.gov.my

Kayan dan Zuraini (2003), Pengurusan Penyenggaraan Bangunan Lama Kerajaan, The Malaysian Surveyors, Vol38, No. 1, 2003

Maintain Our Heritage (2004), Putting it off: How lack of Maintenance Fails our Heritage, Maintain our Heritage, Bath.

Mohammad Ashraf, Zainal Abidin dan Siti Nor Fatimah (2010), Penyenggaraan Bangunan Warisan: Isu, Dilema dan Strategi, National Conference on Promotion and Preservation of Heritage 2010, 24 - 26 Nov 2010, Park Royal, Pulau Pinang

Mohammad Ashraf, Zainal Abidin dan Siti Nor Fatimah (2012), The Importance of On-going Maintenance in Preserving the Heritage Listed Buildings, International Journal on Advanced Science, Engineering and Information Technology, Volume 2 (2012) No 2, page $83-85$.

Seeley H. (1976), Building Maintenance, Macmillan Press Ltd, London

Wood B. (1999), Inteligent Building Care, Journal of Facilities, Vol. 17, No. 5/6, 1999 